\title{
Evaluation of the Image-Pro Plus 4.5 software for automatic counting of labeled nuclei by PCNA immunohistochemistry
}

\section{Avaliação do programa Image-Pro Plus 4.5 para contagem automática de núcleos imunopositivos para PCNA}

\author{
Jairo Silva Francisco* \\ Heleno Pinto de Moraes** \\ Eliane Pedra Dias**
}

\begin{abstract}
The objective of this study was to create and evaluate a routine (macro) using Image-Pro Plus 4.5 software (Media Cybernetics, Silver Spring, USA) for automatic counting of labeled nuclei by proliferating cell nuclear antigen (PCNA) immunohistochemistry. A total of 154 digital color images were obtained from eleven sections of reticular oral lichen planus stained by PCNA immunohistochemistry. Mean density (gray-level), red density, green density, blue density, area, minor axis, perimeter rate and roundness were parameters used for PCNA labeled nuclei discrimination, followed by their outlined presentation and counting in each image by the macro. Mean density and area thresholds were automatically defined based, respectively, on mean density and mean area of PCNA labeled nuclei in the assessed image. The reference method consisted in visual counting of manually outlined labeled nuclei. Statistical analysis of macro results versus reference countings showed a very significant correlation $\left(r_{s}=0.964, p<0.001\right)$ for general results and a high level $(89.8 \pm 3.8 \%)$ of correctly counted labeled nuclei. We conclude that the main parameters associated with a high correlation between macro and reference results were mean density (gray-level) and area thresholds based on image profiles; and that Image-Pro Plus 4.5 using a routine with automatic definition of mean density and area thresholds can be considered a valid alternative to visual counting of PCNA labeled nuclei.
\end{abstract}

DESCRIPTORS: Image processing, computer-assisted; Lichen planus; Proliferating cell nuclear antigen.

\begin{abstract}
RESUMO: O objetivo deste trabalho foi desenvolver e avaliar uma macro (rotina informatizada) usando o programa Image-Pro Plus 4.5 (Media Cybernetics, Silver Spring, EUA) para a contagem automática de núcleos imunopositivos para o antígeno nuclear em célula proliferante (PCNA). Utilizamos 154 imagens microscópicas digitalizadas coloridas obtidas de onze cortes histológicos de líquen plano oral reticular processados por imuno-histoquímica para PCNA. Os parâmetros densidade média (nível de cinza), densidades de vermelho, de verde e de azul, área, eixo menor, taxa de perímetro e redondeza foram usados para a discriminação dos núcleos imunopositivos pela macro, que, no final do processo, apresentava estes núcleos delineados e contados na imagem estudada. A definição dos limites de corte para densidade média e área foi realizada automaticamente em função, respectivamente, da média da densidade e da média da área dos núcleos imunopositivos presentes em cada imagem. Para controle, foi realizado o delineamento manual dos núcleos imunopositivos sobre as imagens digitalizadas e sua contagem visual. A comparação entre os resultados das contagens da macro versus contagens do controle mostrou uma correlação estatística significativa $\left(r_{\mathrm{s}}=0,964, \mathrm{p}<0,001\right)$ e uma alta proporção $(89,8 \pm 3,8 \%)$ de núcleos imunopositivos contados coerentemente pela macro. Concluímos que os principais parâmetros associados com a alta correlação entre os resultados da macro e do controle foram os limites de corte para densidade média (nível de cinza) e área baseados no padrão das imagens. Além disso, a análise de imagem usando o Image-Pro Plus 4.5 com definição automática dos limites de corte para densidade média e área pode ser considerada uma alternativa válida para o método visual de contagem de núcleos imunopositivos para PCNA.
\end{abstract}

DESCRITORES: Processamento de imagem assistida por computador; Líquen plano; Antígeno nuclear de célula em proliferação.

\section{INTRODUCTION}

Proliferating cell nuclear antigen (PCNA) is a $36 \mathrm{kD}$ nuclear acidic protein with high expression levels in late G1 and S cell cycle phases. Thus, an immunohistochemical study of PCNA is an alternative to cellular proliferative analysis ${ }^{7}$.
Advantages of computer-assisted image analysis for immunostaining quantification have compared this method with conventional analysis (based on microscopic observation). They include: better reproducibility and quick results ${ }^{2,4,6}$.

\footnotetext{
* Master's Degree Student in Buccodental Pathology; ** Adjunct Professors - Graduate Course in Pathology, School of Medicine, Fluminense Federal University.
} 
Francisco JS, Moraes HP, Dias EP. Evaluation of the Image-Pro Plus 4.5 software for automatic counting of labeled nuclei by PCNA immunohistochemistry. Braz Oral Res 2004;18(2):100-4.

Konstantinidou et al. ${ }^{3}$ (1997) and Weaver, $\mathrm{Au}^{9}$ (1997) evaluated the computer-assisted image analysis to score PCNA labeled nuclei. Their results showed a high correlation between image analysis and visual scores (correlation coefficients: $\mathrm{r}=0.820$, and $\mathrm{r}=0.882$, respectively). These studies concluded that computer-assisted image analysis is a valid alternative for scoring PCNA immunostaining in individual cells.

Image-Pro Plus 4.5 (Media Cybernetics, Silver Spring, USA) is an image analysis software used for quantification in several immunohistochemical studies $^{5}$. However, no study using this software for PCNA quantitative analysis was found. Thus, the objective of our study was to create and evaluate a routine (macro) using Image-Pro Plus 4.5 for automatic counting of labeled nuclei by PCNA immunohistochemistry.

\section{MATERIALS AND METHODS}

Eleven paraffin-embedded specimens of reticular oral lichen planus registered between 1989 and 2000 at the Antônio Pedro University Hospital (Niterói, Brazil) were used. One section (5 $\mu \mathrm{m}$ thick) from each specimen was previously processed by PCNA immunohistochemistry by Braga ${ }^{1}$ (2001). After being placed on silane coated slides, tissue sections were deparaffinized, rehydrated, and submitted to heat-induced antigen retrieval by microwaving the slides at $700 \mathrm{~W}$ for $9 \mathrm{~min}$ in $0.01 \mathrm{M}$ citrate buffer pH 6.0 (Laboratory of Pathology, Fluminense Federal University, Niterói, Brazil). Endogenous peroxidase activity was blocked by incubation for $15 \mathrm{~min}$ in a $3 \% \mathrm{H}_{2} \mathrm{O}_{2}$ solution (Laboratório ADV, São Paulo, Brazil) at room temperature. Non-specific binding sites were blocked by incubation in normal goat serum (Dako Corp., Carpenteria, USA) (dilution: 1/100) for $30 \mathrm{~min}$. Tissue sections were incubated with anti-PCNA antibodies (dilution: 1/500 - PC10 code M879, Dako Corp., Carpenteria, USA) for $30 \mathrm{~min}$ at $37^{\circ} \mathrm{C}$ and with Envision (Envision System, Dako Corp., Carpenteria, USA) for one hour at room temperature. Visualization was performed by incubation for $5 \mathrm{~min}$ in 3,3'diaminobenzidine (Dako Corp., Carpenteria, USA). In the interval between each step, sections were washed with distilled water and rinsed three times in phosphate buffered saline (PBS 0.01 M, pH 7.4, Laboratory of Pathology, Fluminense Federal University, Niterói, Brazil) for 10 min. Finally, the slides were counterstained with Mayer's hematoxilin (Laboratory of Pathology,
Fluminense Federal University, Niterói, Brazil) for 3 min, dehydrated and coverslipped. Human tonsil sections were used as positive staining control.

These sections were viewed through a Labophot-2 optical microscope with a Plan $40 \mathrm{X} / 0.70$ objective (Nikon, Tokyo, Japan). Digital images were captured by an Iris CCD color video camera (Sony, Tokyo, Japan) mounted on top of the microscope. This camera was connected to a $500 \mathrm{MHz}$ Pentium-III (Intel Corp., Austin, USA) personal computer by a 4 MB PCI All-in-Wonder Pro image card (ATI Technologies, Santa Clara, USA). The three color channels of the camera were balanced by adjusting the microscope light intensity and camera gain and offset, using an ATI image card software. Images were viewed in a 15" Syncmaster 500S color monitor (Samsung Corp., Kyungki-Do, Korea).

A total of 154 images (fourteen from each section) were digitized and stored in uncompressed tiff format (tagged image file format) with 24-bit RGB class and $640 \times 480$ pixel resolution.

The nuclei were considered positive for PCNA labeling if their immunostains were equal or larger than 50 percent of the nuclear area. Weak brown stains were excluded from the counting.

Based on their visual identification, the PCNA positive nuclei in all images were outlined in green using Photoshop 6.0 (Adobe Systems Incorporated, San Jose, USA). These images were named "reference images" (Figure 1). The nuclei outlined in green were counted image per image, and reference countings were defined.

The macro for counting PCNA immunostained nuclei in the stored images was developed using Image-Pro Plus 4.5. The labeled nuclei image segmentation was based on RGB 8-bit per channel parameters: red (100-210), green (85-190), and blue (80-180). The segmented areas in the images were filtered to count PCNA labeled nuclei with $50 \%$ or more of their nuclear area with strong or moderate immunostaining. This filtering used thresholds as follows: mean density (minimum $=115$; maximum $=164-169$, proportionally for labeling mean density per image), red density (125-185), green density (110-172), blue density (110-172), area (minimum $=$ labeled nuclear mean area per image /2.3), axis (minimum $=2 \mu \mathrm{m})$, roundness (0.6$1.0)$, and perimeter ratio (0.5-1.0). Mean density and area thresholds were automatically defined based, respectively, on mean density and mean area of PCNA labeled nuclei in the assessed image. After macro application, the PCNA labeled 
Francisco JS, Moraes HP, Dias EP. Evaluation of the Image-Pro Plus 4.5 software for automatic counting of labeled nuclei by PCNA immunohistochemistry. Braz Oral Res 2004;18(2):100-4.



FIGURE 1 - Reference image: the PCNA positive nuclei in all images were manually outlined based on visual identification (immunohistochemistry for PCNA, oral lichen planus).

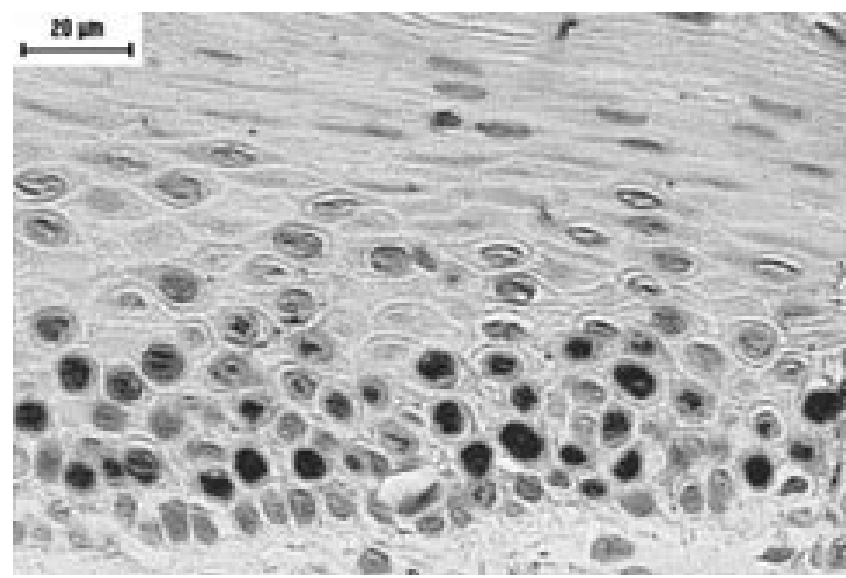

FIGURE 2 - Macro image: the PCNA labeled nuclei were automatically outlined and counted by the macro (immunohistochemistry for PCNA, oral lichen planus).

TABLE 1 - Counting results of PCNA immunohistochemistry labeled nuclei in the 154 studied images (fourteen per case).

\begin{tabular}{c|r|r|r|r|r|r|r|r|r|r|r|r}
\hline \hline Case & \multicolumn{2}{|c|}{ Reference* } & \multicolumn{2}{|c|}{ Macro } & \multicolumn{2}{|c|}{ Coherent } & \multicolumn{2}{|c|}{ Included } & \multicolumn{2}{|c|}{ Excluded } & \multicolumn{2}{|c}{ Overmarked } \\
\hline A & 115 & $100.0 \%$ & 124 & $107.8 \%$ & 97 & $84.3 \%$ & 27 & $23.5 \%$ & 16 & $13.9 \%$ & 2 & $1.8 \%$ \\
\hline B & 371 & $100.0 \%$ & 413 & $111.3 \%$ & 347 & $93.5 \%$ & 66 & $17.8 \%$ & 14 & $3.8 \%$ & 10 & $2.7 \%$ \\
\hline C & 269 & $100.0 \%$ & 288 & $107.1 \%$ & 251 & $93.3 \%$ & 37 & $13.8 \%$ & 9 & $3.4 \%$ & 9 & $3.3 \%$ \\
\hline D & 83 & $100.0 \%$ & 102 & $122.9 \%$ & 78 & $94.4 \%$ & 24 & $28.9 \%$ & 5 & $6.0 \%$ & 0 & $0.0 \%$ \\
\hline F & 102 & $100.0 \%$ & 96 & $94.1 \%$ & 87 & $85.3 \%$ & 9 & $8.8 \%$ & 15 & $14.7 \%$ & 0 & $0.0 \%$ \\
\hline G & 114 & $100.0 \%$ & 113 & $99.1 \%$ & 101 & $88.6 \%$ & 12 & $10.5 \%$ & 12 & $10.5 \%$ & 1 & $0.9 \%$ \\
\hline H & 158 & $100.0 \%$ & 157 & $99.4 \%$ & 137 & $86.7 \%$ & 20 & $12.7 \%$ & 18 & $11.4 \%$ & 3 & $1.9 \%$ \\
\hline I & 385 & $100.0 \%$ & 366 & $95.1 \%$ & 334 & $86.8 \%$ & 32 & $8.3 \%$ & 29 & $7.5 \%$ & 22 & $5.7 \%$ \\
\hline J & 190 & $100.0 \%$ & 349 & $103.9 \%$ & 311 & $92.6 \%$ & 38 & $11.3 \%$ & 16 & $4.7 \%$ & 9 & $2.7 \%$ \\
\hline K & 335 & $100.0 \%$ & 321 & $95.9 \%$ & 295 & $88.1 \%$ & 26 & $7.8 \%$ & 22 & $6.5 \%$ & 18 & $5.4 \%$ \\
\hline Total of nuclei & 2458 & - & 2545 & - & 2218 & - & 327 & - & 166 & - & 74 & - \\
\hline Mean percentage & - & $100.0 \%$ & - & $104.6 \%$ & - & $89.8 \%$ & - & $14.8 \%$ & - & $8.0 \%$ & - & $2.2 \%$ \\
\hline Standard deviation & - & - & - & $9.0 \%$ & - & $3.8 \%$ & - & $6.8 \%$ & - & $4.0 \%$ & - & $2.0 \%$ \\
\hline \hline
\end{tabular}

*All percentage values were related to the reference (visual) countings.

nuclei were viewed outlined with yellow in the images (named "macro images" - Figure 2) and their counting per image was obtained.

Comparing the 154 macro images with their respective reference images, the scores of PCNA labeled nuclei, correctly and incorrectly counted by the automatic routine, were defined. These results were analyzed with SPSS 10.0 statistical software (SPSS Inc., Chicago, USA).

\section{RESULTS}

Results of reference and automatic countings are presented in Table 1. Detailed countings of 
Francisco JS, Moraes HP, Dias EP. Evaluation of the Image-Pro Plus 4.5 software for automatic counting of labeled nuclei by PCNA immunohistochemistry. Braz Oral Res 2004;18(2):100-4.

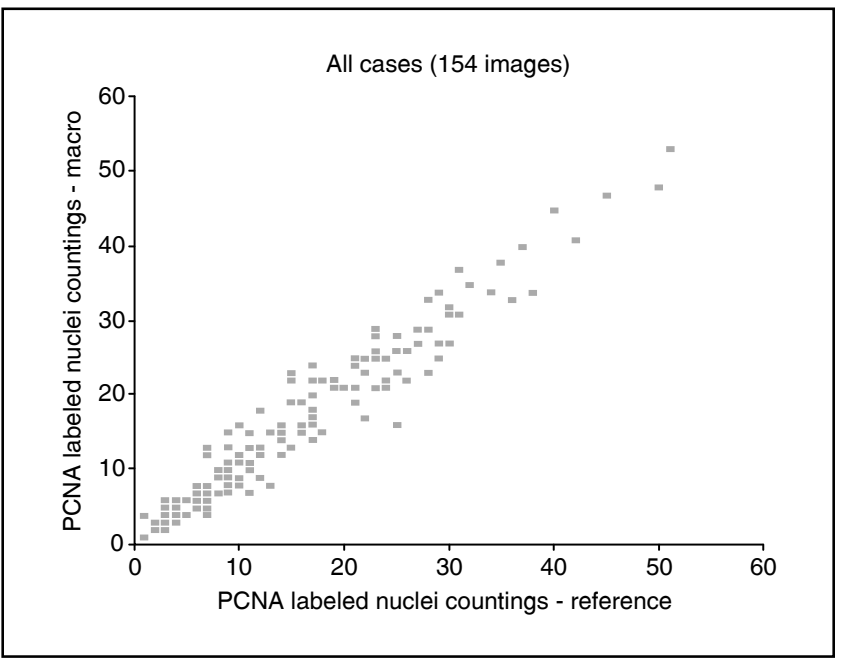

GRAPH 1 - Diagrammatic presentation of the correlation between macro and reference countings of PCNA labeled nuclei for the 154 images (Spearman correlation coefficient $r_{s}=0.964, p<0.001$, bi-tailed).

PCNA labeled nuclei were obtained by comparing reference versus macro respective images: the PCNA labeled nuclei correctly counted by the macro (coherent), those incorrectly included by the macro (included), those excluded by the macro (excluded), and those counted together (overmarked). Percentage values are related to reference (visual) countings. Graph 1 shows the correlation between counting values for 154 macro images versus reference images. Both counting methods presented a very high Spearman nonparametric correlation coefficient $\left(r_{s}=0.964, p<0.001\right.$, bi-tailed).

\section{DISCUSSION}

Image-Pro Plus 4.5, in our opinion, has limitations and tools compatible with other image analysis software. Moreover, the parameter values applied to this study can be useful in other studies on PCNA immunostaining image analysis.

The weak or small PCNA immunostains were not counted because of their occurrence in nonproliferating cells ${ }^{7}$. Therefore, the quiescent cell labeled nuclei with low PCNA expression levels had higher chances of being excluded from the counting.

Weaver, $\mathrm{Au}^{9}$ (1997) obtained a high correlation coefficient $(\mathrm{r}=0.882)$ when they compared image analysis [using size (area), gray-level (mean density) and proportion of labeled nuclear area] and visual counting of PCNA labeled nuclei in head and neck, and bladder tumors. Using the same mate- rial, Weaver, $\mathrm{Au}^{8}$ (1997) assessed the automatic threshold definition applicability, and concluded that the automatic gray-level (mean density) and hue thresholds improved the accuracy and the reproducibility of image analysis results.

The mean density and area thresholds in Image-Pro Plus 4.5 macro were the most important parameters used in PCNA labeled nuclei discrimination. This profile is similar to the PCNA immunostaining image analysis performed by Konstantinidou et al. ${ }^{3}$ (1997). The macro auxiliary parameters were as follows: red density, green density, blue density, minor axis, perimeter rate and roundness. The perimeter rate and roundness parameters were also used by Konstantinidou et $a .^{3}$ (1997).

The assessed material showed a variation in the PCNA labeling intensity in all cases. This profile was incompatible with the use of fixed thresholds for labeled nuclei mean density. However, if cut limits are placed in an adequate manner for the intermediary intensity pattern, images with greater intensity marks would tend to include inadequate nuclei in the count. The opposite happens with images of less relative intensity. To avoid this, Konstantinidou et al. ${ }^{3}$ (1997) used an interactive introduction of the mean density thresholds related to the brown labeling intensity, and Weaver, $\mathrm{Au}^{8}$ (1997) used a preliminary sub-routine for the automatic definition of the mean density thresholds in the image analysis for PCNA immunohistochemistry.

We also applied automatic selection of the mean density thresholds. In order to make this possible, the program analyzed the mean density of the PCNA labeled nuclei in each studied image so that, in the sequence, the mean density threshold for counting the acceptable labeled nuclei was defined.

A significant variation in the area of PCNA nuclear immunostains was observed in the studied sections. To select the minimal area threshold, other authors used the interactive definition of minor value for acceptable immunostained areas in the images. The minimal area threshold in our study was empirically defined using the mean area of immunostains per image divided by 2.3 (this value was obtained based on preliminary analysis of the assessed images - data not shown).

The automatic routine we used has a greater potential of reproducibility because of routine runs with only "one button command", which accomplishes the definition of PCNA immunostaining 
Francisco JS, Moraes HP, Dias EP. Evaluation of the Image-Pro Plus 4.5 software for automatic counting of labeled nuclei by PCNA immunohistochemistry. Braz Oral Res 2004;18(2):100-4.

area and mean density thresholds resulting in an instantaneous positive nuclei counting per image.

The statistical analysis among macro counting results versus reference countings showed a high correlation coefficient $\left(r_{s}=0.964, p<0.001\right)$. This means that there is an underlying proportion among both countings. There was a high level of PCNA labeled nuclei correctly counted by the macro (Table 1 , coherent $=89.8 \pm 3.8 \%$ ), indicating good sensitivity (proportion of the acceptable PCNA labeled nuclei that were recognized by the macro). These findings are associated with the automatic

\section{REFERENCES}

1. Braga BRS. Análise da atividade proliferativa no líquen plano oral [Dissertação de Mestrado]. Niterói: Universidade Federal Fluminense; 2001.

2. Francis IM, Adeyanju MO, George SS, Junaid TA, Luthra UK. Manual versus image analysis estimation of PCNA in breast carcinoma. Anal Quant Cytol Histol 2000;22:116.

3. Konstantinidou A, Patsouris E, Kavantzas N, Pavlopoulos PM, Bouropoulou V, Davaris P. Computerized determination of proliferating cell nuclear antigen expression in meningiomas. A comparison with non-automated method. Gen Diagn Pathol 1997;142:311-6.

4. Lin HC, Sotnikov AV, Fosdick L, Bostick RM, Willett WC. Quantification of proliferating cell nuclear antigen in large intestinal crypt by computer-assisted image analysis. Cancer Epidemiol Biomarkers Prev 1996;5:109-14. reproducibility potential and support the macro practical applicability.

\section{CONCLUSION}

The main parameters associated with a high correlation between macro and reference results were mean density (gray-level) and area thresholds based on image profiles.

Image-Pro Plus 4.5, using a routine with automatic definition of mean density and area thresholds, can be considered a valid alternative to visual counting of PCNA labeled nuclei.

5. Media Cybernetics. Image-Pro Plus - application notes. Silver Spring: Media Cybernetics; 2002. Available from: URL: $h t t p: / / w w w . m e d i a c y . c o m /$ action. $h t m$.

6. Seidal T, Balaton AJ, Battifora H. Interpretation and quantification of immunostains. Am J Surg Pathol 2001;25:12047 .

7. Somanathan S, Suchyna TM, Siegel AJ, Berezney R. Targeting of PCNA to sites of DNA replication in the mammalian cell nucleus. J Cell Biochem 2001;81:56-67.

8. Weaver JR, Au JL. Application of automatic thresholding in image analysis scoring of cells in human solid tumors labeled for proliferation markers. Cytometry 1997;29:128 35.

9. Weaver JR, Au JL. Comparative scoring by visual and image analysis of cells in human solid tumors labeled for proliferation markers. Cytometry 1997;27:189-99.

Received for publication on Jun 30, 2003

Sent for alterations on Aug 19, 2003 Accepted for publication on Apr 05, 2004 